\title{
Streptomyces paraguayensis
}

National Cancer Institute

\section{Source}

National Cancer Institute. Streptomyces paraguayensis. NCI Thesaurus. Code C125958.

A species of gram-positive, aerobic actinomycetes bacteria in the genus Streptomyces

that has a branching, filamentous growth pattern and is associated with black grained mycetoma disease in humans. 